\title{
Study of 11 September 2004 hailstorm event using radar identification of 2-D systems and 3-D cells
}

\author{
M. Ceperuelo ${ }^{1}$, M. C. Llasat ${ }^{1}$, L. López ${ }^{2}$, E. García-Ortega ${ }^{2}$, and J. L. Sánchez ${ }^{2}$ \\ ${ }^{1}$ Department of Astronomy \& Meteorology, Faculty of Physics, University of Barcelona, Spain \\ ${ }^{2}$ Laboratory for Atmofpheric Physics, University of León, Spain
}

Received: 7 October 2005 - Revised: 9 February 2006 - Accepted: 13 February 2006 - Published: 8 March 2006

\begin{abstract}
The most important hail event recorded in the region of the Ebro Valley (NE Spain) in 2004 was the 11 September episode. Large hailstones (some of them with a diameter of over $30 \mathrm{~mm}$ ) caused important damages in agriculture and properties. The hail event affected an area of 3848 ha and was caused by several multicellular systems. The aim of this paper is the analysis of the associated convective structures using the meteorological radar as well as the MM5 mesoscale model, thermodynamic data and a hailpad network. To achieve this end, the new hailstorm analysis tool RHAP (Rainfall events and Hailstorms Analysis Program) has been applied. It identifies tracks and characterises precipitation systems and convective cells, taking into account 2-D and 3-D structures. The event has also been studied with the TITAN software (Thunderstorm Identification, Tracking, Analysis and Nowcasting) in an attempt to compare both methods. Results show that the episode had a strong convective activity with CAPE values over $4000 \mathrm{~J} / \mathrm{kg}$ and with hail-forming cells characterised by VIL (Vertical Integrated Liguid) exceeding $40 \mathrm{~kg} / \mathrm{m}^{2}$, VILD (VIL density) over $4 \mathrm{~g} / \mathrm{m}^{3}$, HP (Hail Probability) of $100 \%$ and SHP (Severe Hail Probability) of over $75 \%$. The hail cells evolved into multicellular systems that lasted between 70 and $90 \mathrm{~min}$. Finally, the comparison of RHAP and TITAN has shown significant correlations between methods.
\end{abstract}

\section{Introduction}

The most important hail event in 2004 in the Ebro Valley (area of about $40000 \mathrm{~km}^{2}$ ), North-East of Spain (Fig. 1), occurred on 11th September 2004. The event affected a region of over $2500 \mathrm{~km}^{2}, 15 \%$ of which is covered by a hailpad network belonging to the ADV, "Associació de Defensa dels Vegetals" (Association for the Protection of Plants) in Lleida (Fig. 1). This network is formed by 170 hailpads and its den-

Correspondence to: M. Ceperuelo

(ceperuel@am.ub.es) sity is close to 1 hailpad per $16 \mathrm{~km}^{2}$ and provides, among other data, values of maximum hail size, ice mass, kinetic energy and number of impacts per $\mathrm{m}^{2}$ (Schleusener and Jenings, 1960; López, 2003). A total of 19 hailpads were hit by hailstones during this event, damaging 3,848 ha of crops including apples of the Golden Delicious type, pears, peaches and nectarines. The largest hailstones were registered in the towns of Fraga and Alcarrás (Fig. 1), with a maximum hail size of $34.6 \mathrm{~mm}$.

Summer storms are very frequent in the study zone, where an average number of 32 thunderstorm days per year have been registered in the south-western part, area of about $25000 \mathrm{~km}^{2}$, (Font, 1983). Previous studies (Pascual, 2000; López, 2003) have shown that the medium size of hailstones in this area is usually under $20 \mathrm{~mm}$ and this size is usually registered around 16:00 UTC, after the maximum irradiance value. From a mesoscale point of view, hailstorm events are associated with atmospheric instability, strong updrafts and highly organised convective systems (Ragette, 1973; Browning, 1977; Knight and Knight, 2001; Martín et al., 2001). López (2003) found that in this area an average CAPE (Convective Available Potential Energy) value of $1020 \mathrm{~J} / \mathrm{Kg}$ is required to cause convective activity related with hail, while the Total of Totals index has an average value of 47.3. Various studies have been carried out in order to classify associated convective systems using the meteorological radar and taking into account 2-D and 3-D features (Fraile at al., 2001; Sánchez at al., 2003; Rigo, 2004; Rigo and Llasat, 2004).

These thermodynamic features together with the evolution of convective systems (2-D and 3-D) associated to the 11 September 2004 event are explored in this paper. To achieve this end, different meteorological data and hailpad data have been integrated using software developed by the University of Barcelona: RHAP (Rainfall events and Hailstorms Analysis Program). More detailed information about this software can be found elsewhere in this issue (Ceperuelo et al., 2005). The present paper starts with the description of the data base and the methodology employed. Then, the synoptic scale and mesoscale circulation obtained with the MM5 


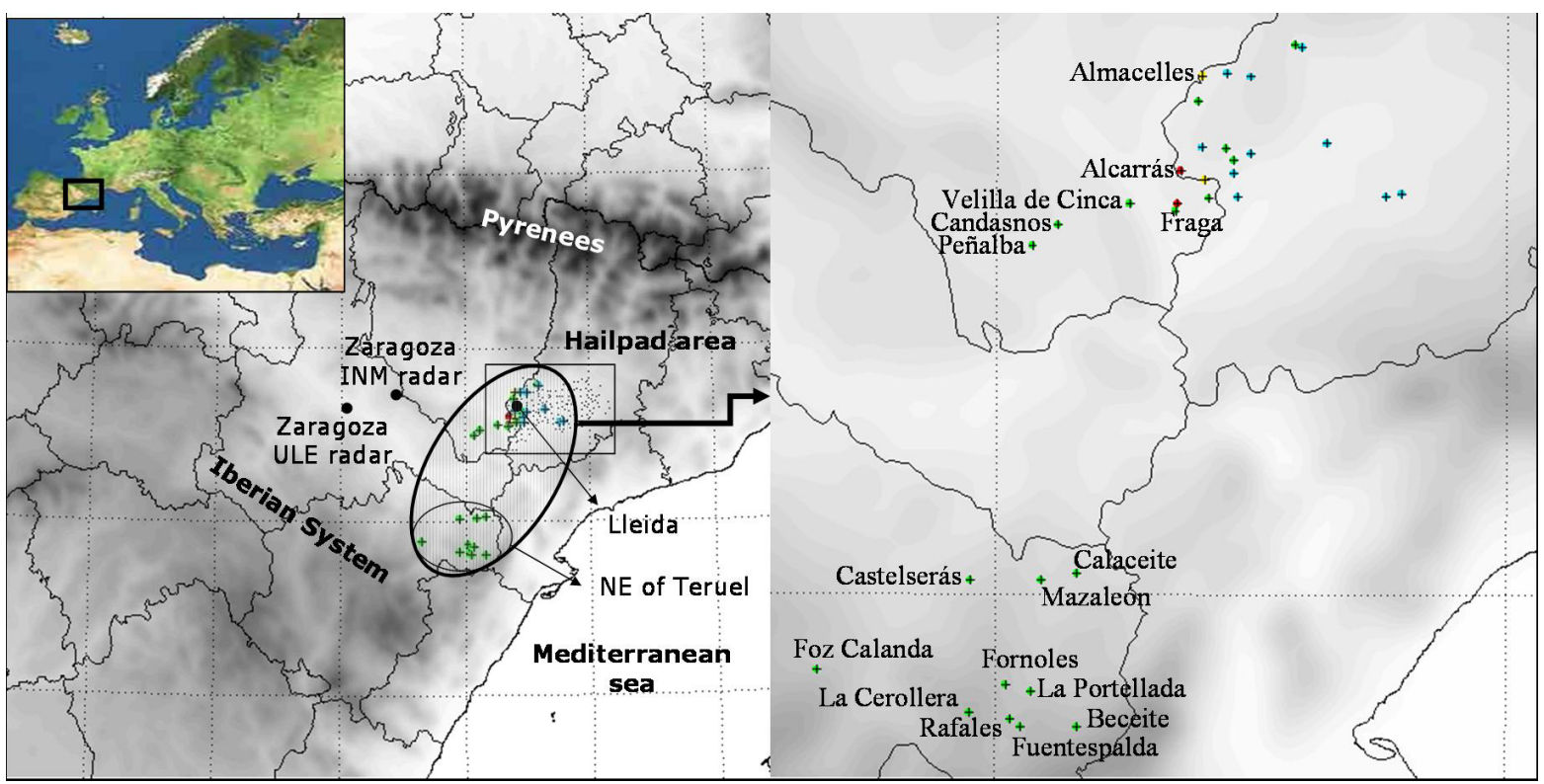

Fig. 1. Study area and locations.

Table 1. University of Leon radar and INM radar features.

\begin{tabular}{lll}
\hline Feature & INM radar & ULE radar \\
\hline Beamwidth & $0.9^{\circ}$ & $1.65^{\circ} \mathrm{max}$ \\
Frequency & $5600-5650 \mathrm{MHz}$ & $5485-5600 \mathrm{MHz}$ \\
Pick power & $250 \mathrm{~kW}$ & $250 \mathrm{~kW}$ \\
Pulse width & $2 \mu \mathrm{s}$ & $2 \mu \mathrm{s}$ \\
PRF & $250 \mathrm{~Hz}$ & $250 \mathrm{~Hz}$ \\
\hline
\end{tabular}

meteorological model and the upper-air soundings are explained. The next section includes the radar characterisation and the tracking of 3-D cells and precipitation systems that produce hailstones. The results in the analysis of hail cells obtained using RHAP and using TITAN are then compared. Finally, conclusions are presented.

\section{Database and methodology}

To study the 11th September 2004 hail event, a wide range of data have been used: radar data, upper-air sounding data, hailpad data and MM5 model outputs. First of all, ground observations provided by the ADV hailpad network and meteorological observers were obtained. These data have been analysed and verified using radar data. Thermodynamic data were obtained from the 12:00 UTC Lleida radiosounding.

The meteorological radars used (Fig. 1) were the Zaragoza radar from the Spanish National Institute for Meteorology (Instituto Nacional de Meteorología, INM) and the Zaragoza radar from the University of León (ULE), Spain. The main radar features are shown in Table 1, and the main radar differ- ence is that the time step of the ULE radar is $3 \mathrm{~min}$, whereas in the case of the INM radar it is $10 \mathrm{~min}$.

The 11th September 2004 event has been studied focusing on the Zaragoza INM radar and the radar parameters used for characterising the event were: VIL "Vertical Integrated Liquid" (Greene and Clark, 1972), VILD "VIL density" (Amburn and Wolf, 1997), VOD "VIL of the Day" (San Ambrosio, 2005; Paxton and Shepherd, 1993), H45 "Waldvogel Parameter" and HP "Hail Probability" (Waldvogel et al., 1979), SHP "Severe Hail Probability" (Witt et al., 1998), MEHS "Maximum Expected Hail Size" (Witt et al., 1998), kinetic energy (Waldvogel et al., 1978 and Witt et al., 1998) and ECHOTOPS of 20, 30 and $40 \mathrm{dBZ}$. The objective of combining all of these parameters is to produce a good indicator of hail evidence. For example, VIL is an approximation of vertical liquid content and VOD is an empirical index of hail presence that can be used to establish a threshold of hail and no hail evidence. In the case of VOD, HP, H45, MEHS and SHP, thermodynamic data from an upper-air sounding are required.

On the other hand, data from the Mesoscale Meteorological model MM5 have been used in order to obtain wind fields at four different levels $(925,850,700$ and $500 \mathrm{hPa})$ to carry out the 3-D-cells tracking of the hail event. The initial and boundary conditions come from the FNL/NCEP analyses $\left(1^{\circ}\right.$ latitude $\times 1^{\circ}$ longitude, every $6 \mathrm{~h}$ ), and the model parameterisation applied here is shown in Table 2).

All these data have been integrated using RHAP software (Ceperuelo at al., 2006). The RHAP techniques used for identifying and characterising 3-D cells are an improved version of the SCIT algorithms (Johnson et al., 1998; Rigo and Llasat, 2004) and an improved version of the 3-D tracking method in TITAN (Dixon and Wiener, 1993). The 3-D cells 
Table 2. MM5 parameterisations.

\begin{tabular}{llll}
\hline Parameterisation & D1 & D2 & D3 \\
\hline Moisture scheme & Reisner2 & Reisner2 & Reisner2 \\
Cumulus scheme & BM & KF & Non \\
PBL scheme & MRF & MRF & MRF \\
Radiation scheme & Cloud & Cloud & Cloud \\
Soil scheme & 5-Layer & 5-Layer & 5-Layer \\
Shallow convection & No & No & No
\end{tabular}

tracking algorithm uses the mean wind grid point nearest to the cell centroid to extrapolate the current cell position to the previous position. The mean wind has been obtained using $925,850,700$ and $500 \mathrm{hPa}$. After the position extrapolation, the cell in the previous radar image that satisfies the TITAN condition (the closest and the most similar cell) is searched in order to assign it as a tracked cell. Moreover, RHAP also enables us to identify, characterise and track the precipitation system. The classification of precipitation systems is made on the basis of the proposal by Rigo and Llasat (2004) and includes: mesoscale convective system (MCS), isolated convection (ISO), multicellular (MUL), convective precipitation embedded in stratiform precipitation (EST-EMB) and stratiform precipitation (EST). The classification takes into account the size and duration of the system, as well as the contribution of convective precipitation and stratiform precipitation. For each identified precipitation system it is possible to obtain, among other data, the type of the 2-D system and its size, the percentage of convective precipitation, the maximum reflectivity and the centroid position, the maximum axis, and the 3-D cells involved in the system. For each 3-D cell the following parameters were used: maximum and mean reflectivity, echotop and base mean values, and maximum VIL and VILD values.

\section{Meteorological situation}

The synoptic situation observed on 11th September 2004 at 12:00 UTC showed a thermal depression over the Iberian Peninsula and a cold front in north-western Spain. A trough with a northeast-southwest axis was identified at high levels, $500 \mathrm{hPa}$ (Fig. 2a) and caused a south-west flow over the Iberian Peninsula. The thermal anticyclone situated over North Africa and the Azores high-pressure system were responsible of this situation. A thermal trough was also observed in the northwest of the Iberian Peninsula. This trough was contrasted with the presence of the African continental air mass over the eastern part of the Iberian Peninsula from surface level to $850 \mathrm{hPa}$ (Fig. 2b). This fact and the cold air mass at high levels were the factors that favoured the thunderstorms formed in the study area. This high instability was detected in the thermodynamic analysis, where the hail event was characterised with high values of the instability indices
Table 3. Radiosonde parameters of 11 September 2004 hail event.

\begin{tabular}{ll}
\hline Radiosonde Parameter & Value \\
\hline Lifted Index & -6.3 \\
Showalter Index & -0.8 \\
K Index & 23.4 \\
Total of Totals Index & 51.4 \\
SWEAT index & 231.2 \\
Wind Shear 0-6 km (m/s) & 9.4 \\
Wind Shear 0-1 km (m/s) & 4.5 \\
CAPE (J/kg) & 4322.3 \\
VIL of the Day: VOD “Lewis III" $\left(\mathrm{kg} / \mathrm{m}^{2}\right)$ & 48.4 \\
VOD “Paxton and Shepherd" $\left(\mathrm{kg} / \mathrm{m}^{2}\right)$ & 39.1 \\
Wmax (m/s) & 93.0 \\
$0^{\circ} \mathrm{C}$ height (m) & 4223.7 \\
-20 C height (m) & 6864.0 \\
Precipitable water: SFC-850 $\left(\mathrm{kg} / \mathrm{m}^{2}\right)$ & 14.4 \\
Precipitable water: $850-700\left(\mathrm{~kg} / \mathrm{m}^{2}\right)$ & 7.6 \\
Precipitable water: $700-500\left(\mathrm{~kg} / \mathrm{m}^{2}\right)$ & 2.7 \\
Precipitable water: SFC-300 $\left(\mathrm{kg} / \mathrm{m}^{2}\right)$ & 25.7 \\
\hline
\end{tabular}

(Table 3), with values of CAPE and TTI of $4322.3 \mathrm{~J} / \mathrm{kg}$ and 51.4 respectively.

The convergence zones were located at the South-West of Lleida (Fig. 3) due to low-level wind perturbations caused by the mountains of Iberian System, with heights around $1700 \mathrm{~m}$ (Fig. 1). The low-level wind reanalysis showed a moisture advection over the convergence zones, behind a dry layer at mid-levels $(850-700 \mathrm{hPa})$ with only $7.6 \mathrm{~kg} / \mathrm{m}^{2}$ of precipitable water mass that favoured triggering convection and hail production, as shown in Fig. 3. This figure shows how the convective cells nest zones obtained with radar data agree with the convergence zones obtained with the MM5 meteorological model.

\section{Meteorological Radar and tracking of precipitation systems and 3-D cells}

The radar analysis has shown that the maximum convective activity appeared between 17:00 UTC and 18:00 UTC (Fig. 4) with some values of VIL over $40 \mathrm{~kg} / \mathrm{m}^{2}$, VILD over $4 \mathrm{~g} / \mathrm{m}^{3}$, HP of $100 \%$ and SHP with values over $75 \%$. Hail observations were registered between 15:00 UTC and 19:00 UTC associated to high values of radar parameters $\left(\mathrm{Z}_{\max }>50 \mathrm{dBz}\right)$ in some places. Meanwhile, the maximum hailstone size was registered at the moment of maximum convective activity, with $62.0 \mathrm{dBZ}$ (Fig. 5).

The VOD value using Lewis III was $48.4 \mathrm{~kg} / \mathrm{m}^{2}$ and the VOD value using Paxton and Shepherd (1993) was $39.1 \mathrm{~kg} / \mathrm{m}^{2}$. These high values showed that only cells with high vertical developments could produce hail in this event.

The hailstones registered in the Lleida region were produced by two different cells. The cell that produced the maximum hail size at surface $(34.6 \mathrm{~mm}$ in diameter) was the 

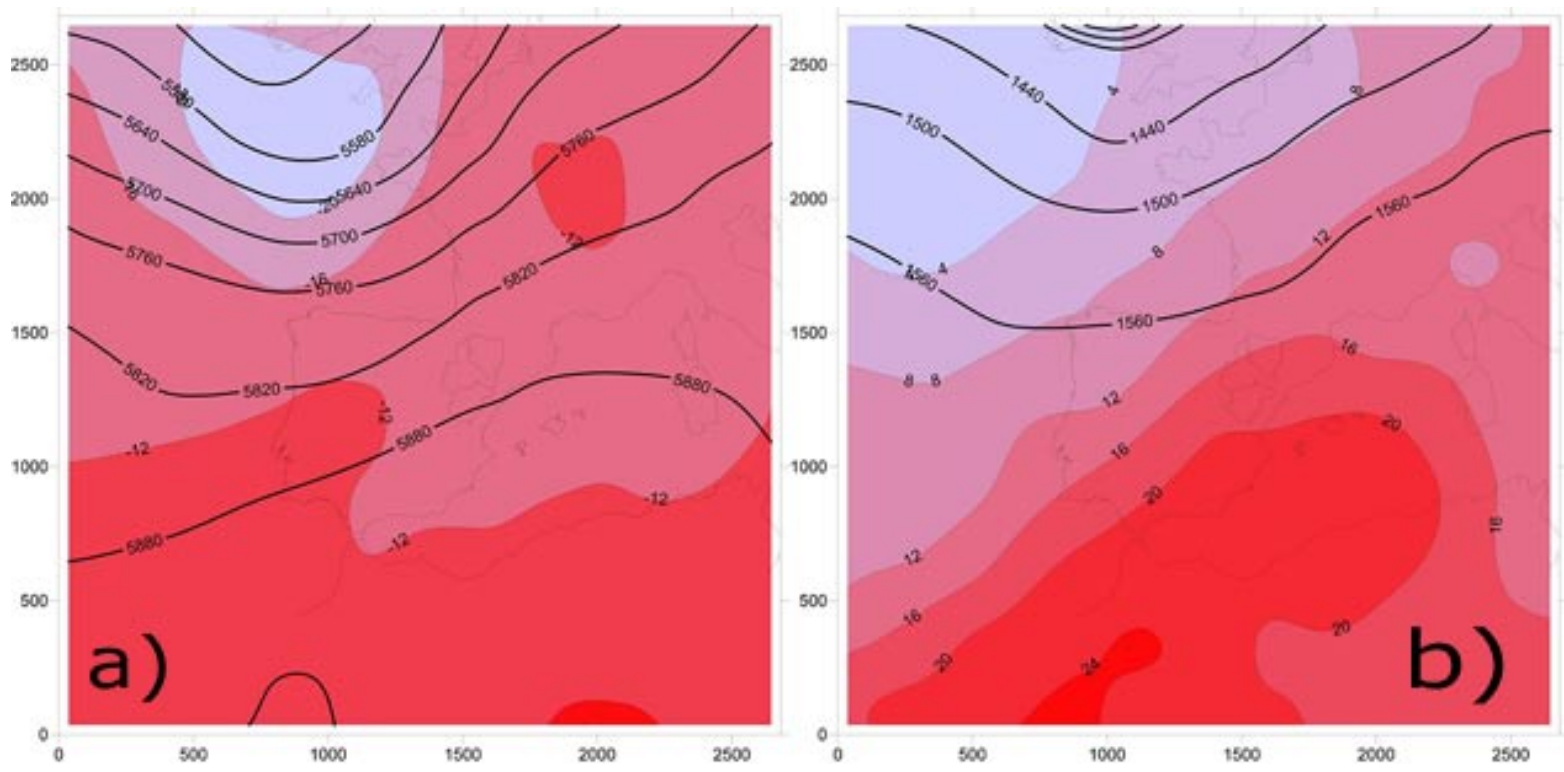

Fig. 2. Geopotential height (contour lines) and temperature (shaded areas) at $500 \mathrm{~Pa}$ (a) and $850 \mathrm{hPa}$ (b).

Table 4. Radar parameters of the 11 September 2004 hail cells at the moment of maximum convective activity: Maximum reflectivity $\left(\mathrm{Z}_{\max }\right)$, Mean reflectivity $\left(Z_{\text {mean }}\right.$ ), Vertical Integrated Liquid (VIL), VIL density (VILD), Kinetic energy (KE), Hail probability (HP), Severe hail probability (SHP) and Maximum expected hail size (MEHS).

\begin{tabular}{|c|c|c|c|c|c|c|c|}
\hline \multirow[b]{2}{*}{ Cell } & \multicolumn{2}{|c|}{ Hailpad area } & \multicolumn{5}{|c|}{ Non-hailpad area } \\
\hline & $\begin{array}{l}\text { Fraga and } \\
\text { Alcarrás cell }\end{array}$ & Almacelles cell & $\begin{array}{l}\text { Foz de } \\
\text { Calanda cell }\end{array}$ & $\begin{array}{l}\text { La Cerollera, } \\
\text { Rafales, } \\
\text { Fuentespalda and } \\
\text { Beceite cell }\end{array}$ & $\begin{array}{l}\text { Castelleserás, } \\
\text { Mazaleón and } \\
\text { Calaceite cell }\end{array}$ & $\begin{array}{l}\text { Fornoles and } \\
\text { La Portellada } \\
\text { cell }\end{array}$ & $\begin{array}{l}\text { Candasnos, } \\
\text { Peñalba } \\
\text { and Velilla de } \\
\text { Cinca cell }\end{array}$ \\
\hline Hail size & $31-45 \mathrm{~mm}$ & $21-30 \mathrm{~mm}$ & Chickpea & Walnut & Walnut & Chickpea & Walnut \\
\hline Time (UTC) & $17: 30$ & $17: 20$ & $15: 20$ & $16: 10$ & $17: 30$ & $18: 10$ & $18: 40$ \\
\hline Latitude & 41.591 & 41.736 & 40.917 & 40.861 & 41.042 & 40.882 & 41.539 \\
\hline Longitude & 0.348 & 0.411 & -0.299 & 0.025 & 0.138 & 0.026 & 0.162 \\
\hline $\mathrm{Z}_{\max }(\mathrm{dBZ})$ & 56.8 & 54.8 & 55.2 & 55.2 & 56.8 & 56.0 & 60.0 \\
\hline$Z_{\text {mean }}(\mathrm{dBZ})$ & 47.8 & 42.2 & 44.0 & 48.4 & 47.4 & 49.2 & 50.0 \\
\hline $\operatorname{VIL}\left(\mathrm{kg} / \mathrm{m}^{2}\right)$ & 38.8 & 11.7 & 26.1 & 45.6 & 35.9 & 19.1 & 63.5 \\
\hline $\operatorname{VILD}\left(\mathrm{g} / \mathrm{m}^{3}\right)$ & 3.7 & 2.3 & 3.7 & 3.6 & 4.2 & 3.2 & 6.0 \\
\hline $\mathrm{KE}\left(\mathrm{J} / \mathrm{m}^{2}\right)$ & 976.4 & 266.3 & 683.4 & 973.0 & 970.4 & 748.3 & 1776.2 \\
\hline HP (\%) & 100 & 48.9 & 75.5 & 100 & 88.8 & 100 & 100 \\
\hline SHP (\%) & 73.3 & 29.6 & 58.5 & 78.1 & 68.3 & 64.6 & 85.8 \\
\hline MEHS (mm) & 70.9 & 12.5 & 39.3 & 85.9 & 58.0 & 50.1 & 116.1 \\
\hline
\end{tabular}

Fraga and Alcarrás cell at 17:30 UTC, with a VIL value of $38.82 \mathrm{~kg} / \mathrm{m}^{2}$, and a VILD value of $3.7 \mathrm{~g} / \mathrm{m}^{3}$ (case 1). These values are close to the empirical value to obtain hail at surface level (VOD). The SHP showed a value of $73.3 \%$, which points to a high likelihood of severe hail at surface level. In non-hailpad-covered areas the hailstones were traced back to 5 different cells, but the problem of this area is that no hail size information is available. However, if we were to compare the values obtained for hail cells in non-hailpad-covered areas to hail cells in hailpad-covered area, we could expect sizes larger than walnuts $(>34 \mathrm{~mm})$ in the latter region. This was the case of the cell that affected Candasnos-PeñalbaVelilla de Cinca (Table 4) and recorded the most intense values of the event, with maximum VIL value of $63.5 \mathrm{~kg} / \mathrm{m}^{2}$, maximum SHP of $85.7 \%$ and MEHS of $11.7 \mathrm{~cm}$. These values were higher than those from cells of the hailpad-covered area. In conclusion, we could expect larger hailstones. This hypothesis was confirmed by the meteorological observers.

The life cycle of the different radar parameters has been calculated in order to know the life cycle of the hailstorms, distinguishing between precipitation systems and 3D cells. The hail system that produced the largest hailstone $(34.6 \mathrm{~mm})$ in the hailpad-covered area, Alcarrás and Fraga cell (case 1), and the hail system that produced hail in the longest-life cell of the non-hailpad-covered area, La Cerollera-Rafales-Fuentespalda-Beceite cell (case 2), have been only studied: 


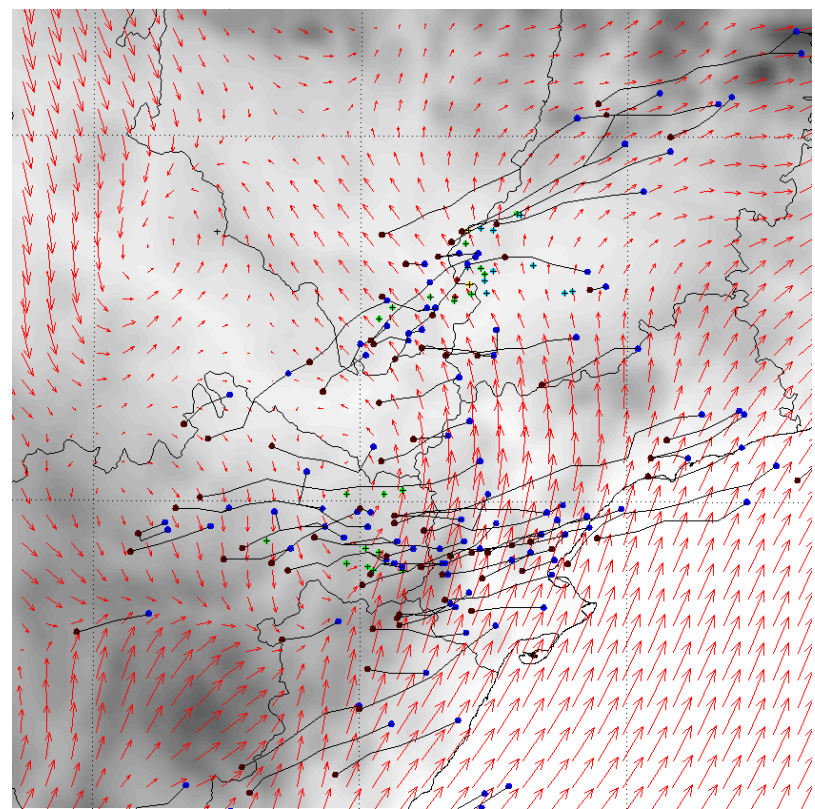

Fig. 3. Trajectories of all the 3-D cells (black lines) of the event and $925 \mathrm{hPa}$ wind field obtained with the MM5 meteorological model at 18:00 UTC (red arrows). Black points are the beginning of the 3-D cells and blue points are the end of the 3-D cells.

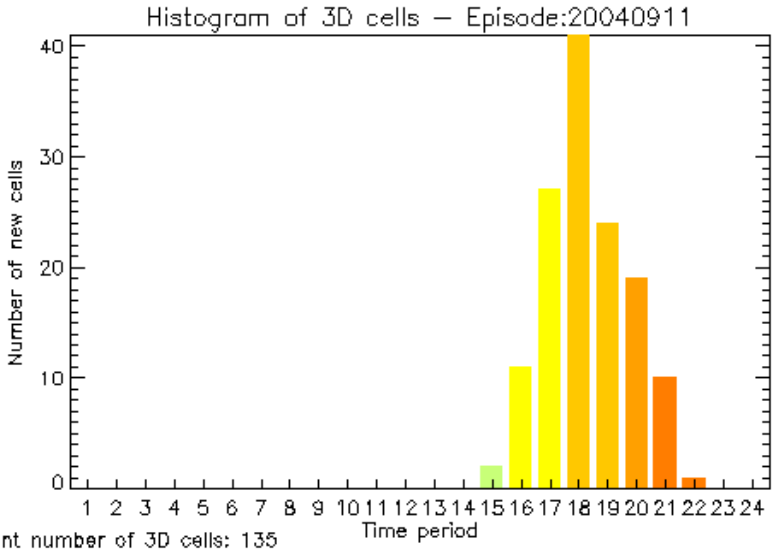

Fig. 4. Histogram of the number of new 3-D cells formed with time resolution of one hour.

\subsection{Precipitation systems}

In case 1 the precipitation structure started at 16:40 UTC as an EST-EMB system. Then it rapidly changed to an ISO system at 16:50 UTC, which lasted $30 \mathrm{~min}$. At 17:30 UTC the system evolved to a MUL system with an area of $992 \mathrm{~km}^{2}$ and eight 3-D cells (four of them over $50 \mathrm{dBZ}$ ) and a percentage of convective precipitation of 56\%. At 17:40 UTC the MUL system merged with a southern MUL system to develop a bigger MUL system with twelve 3-D convective cells. At 18:00 UTC this bigger system split into two different MUL systems. The northern one remained a MUL system until 18:30 UTC.

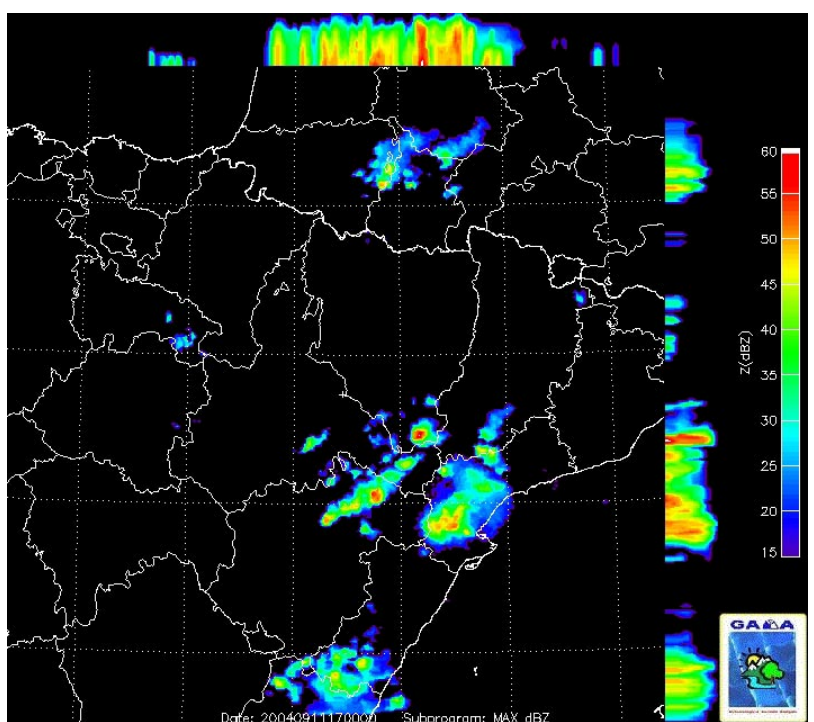

Fig. 5. Maximum reflectivity product of 11 September 2004 hail event at 17:00 UTC (maximum reflectivity value of 62.0 dBZ).

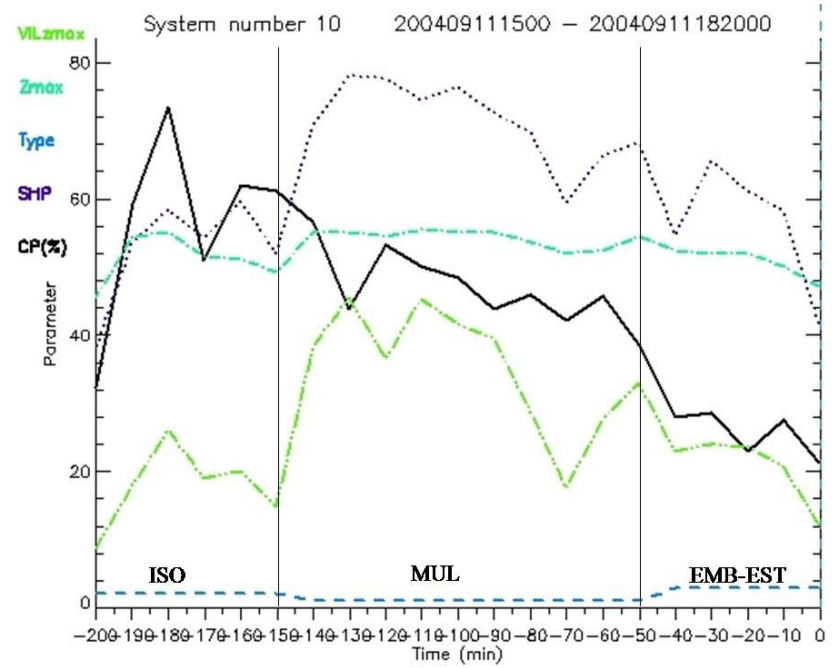

Fig. 6. Time evolution of the precipitation system parameters of the biggest system over the non-hailpad covered area that has produced hail. Time period: from 15:00 UTC to 18:20 UTC. Solid line shows the convective precipitation percentage evolution (\%), dotted line shows de SHP (\%) evolution, dashed line shows the evolution of the type of system, dash-dot line is the evolution of maximum reflectivity (dBZ) and dash-dot-dot line is the time evolution of VIL $\mathrm{Z}_{\text {max }}\left(\mathrm{kg} / \mathrm{m}^{2}\right)$.

The system of case 2 began as an ISO type at 15:00 UTC and lasted until 15:50 UTC. At 16:00 UTC it evolved to a MUL system until 17:30 UTC, when hail precipitated (from 16:00 to 16:40 UTC). Then the system changed to an ESTEMB system until its disappearance. Figure 6 shows the time evolution of the type of system, Zmax, convective precipitation percentage, VILZ and SHP. The area covered by the precipitation system and the biggest hail cell is shown in Fig. 7. 


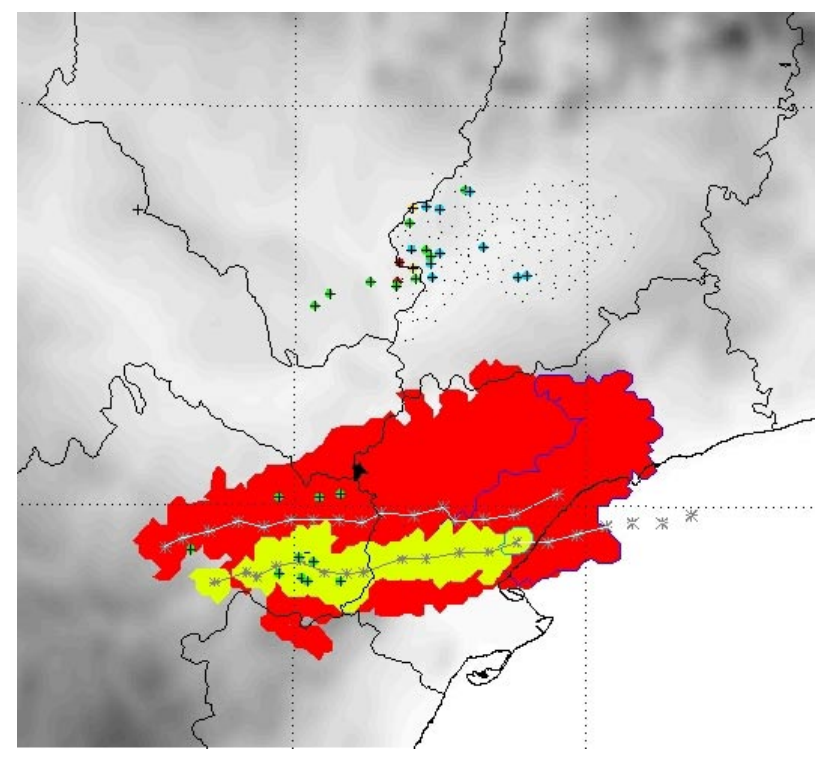

Fig. 7. Trajectory, area covered (15:30-17:30 UTC) and nowcast (60 min) of the La Cerollera-Rafales-Fuentespalda-Beceite cell (case 2), and trajectory and area covered (15:00-17:30 UTC) by the associated precipitation system (red area). Ground hail observations are also shown.

\subsection{3-D cells}

In case 1 a long lived cell of $120 \mathrm{~min}$ was identified (Fig. 8). However, after applying the RHAP reanalysis, based on the strong oscillations of VIL, it is possible to see this long lived cell was three consecutive different cells. The first one was active over the non-hailpad covered area and no hail observations were available. Probably, this cell produced severe hail (hailstones of over $35 \mathrm{~mm}$ ) due to the high values of the different radar parameters: $Z_{\max }=62.0 \mathrm{dBz}, \mathrm{VIL}=54.1 \mathrm{~kg} / \mathrm{m}^{2}$, $\mathrm{VILD}=5.1 \mathrm{~g} / \mathrm{m}^{3}$ (Table 5). The second cell affected the hailpad covered area with hailstones of over $30 \mathrm{~mm}$. It produced hail during thirty minutes with VIL values up to $35 \mathrm{~kg} / \mathrm{m}^{2}$, SHP over $70 \%$ and $Z_{\max }$ over $55 \mathrm{dBZ}$. Finally, the third cell was weaker than the other ones, with high reflectivity values, but small values for VIL and SHP due to the lower values of the tops of the cell.

Case 2 was a long lived cell of $130 \mathrm{~min}$. As in the previous case, this "cell" was composed by two consecutive cells. The first one lasted $100 \mathrm{~min}$ (Table 6) producing hail during 50 min with VIL values over $35 \mathrm{~kg} / \mathrm{m}^{2}$, SHP over $70 \%$ and $\mathrm{Z}_{\max }$ over $54 \mathrm{dBZ}$.

Comparing the two analysed cases, the same hail conditions (VIL $>35 \mathrm{~kg} / \mathrm{m}^{2}, \mathrm{SHP}>70 \%$ and $\mathrm{Z}_{\max }>54 \mathrm{dBZ}$ ) were generally fulfilled.

Finally, after analysing these two cases, a comparison between the two different methods of identifying and tracking 3-D cells (TITAN and RHAP) was carried out. The radar from the University of León located in Zaragoza was used for the TITAN method. The most important difference found between the two identification methods was that TI-

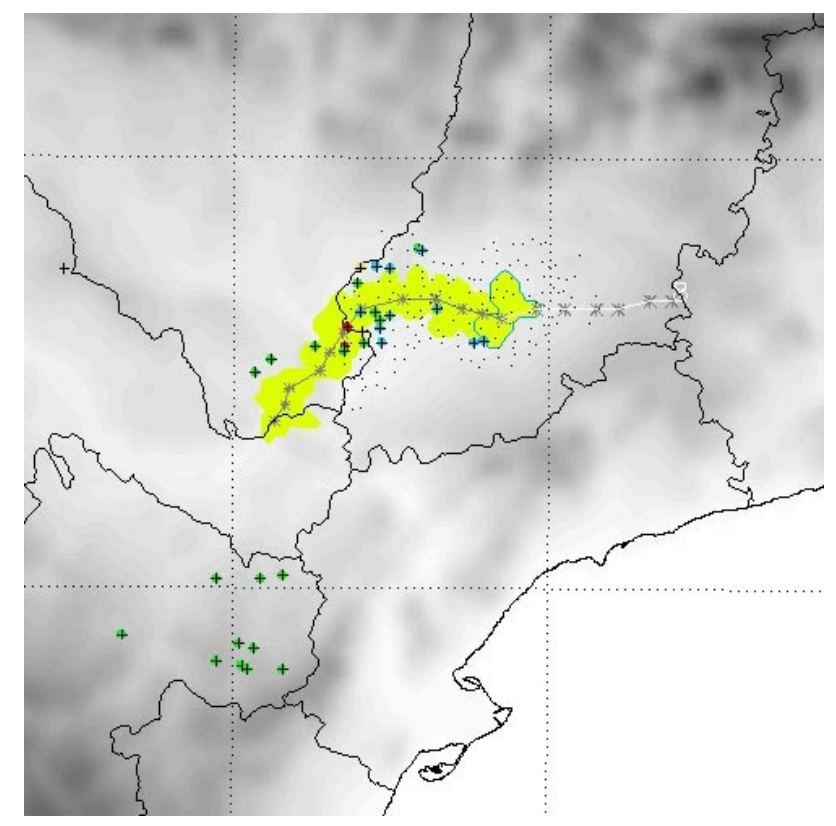

Fig. 8. Trajectory, area covered (16:40-18:30 UTC) and nowcast (60 min) of the Fraga and Alcarrás cell (case 1). Ground hail observations are also shown.

TAN uses only one threshold value ( $30 \mathrm{dBZ}$ ) to identify the cell, whereas the RHAP algorithm uses 7 reflectivity thresholds $(30,35,40,45,50,55,60 \mathrm{dBZ})$. Consequently, where the TITAN identifies one only structure, the RHAP can distinguish between two or more cells (from a spatial point of view as a MUL system and from a temporal point of view following the life cycle of the cells). For this reason, the best correlation between both methods was obtained when the hail was produced by a main cell. The correlation coefficients of reflectivity, tops and volume for the non-hailpad covered area cell have been statistically significant at the 95\% confidence level, largely explaining the variability (Table 7).

\section{Conclusions}

Using the meteorological model results and sounding parameters, we conclude that the convective activity in the 11th September 2004 event was triggered by the synergy of multiple factors: zones of wind convergence, high values of the instability indices, moisture advection at low levels and dry layer at mid-levels $(850-700 \mathrm{hPa})$ with $7.6 \mathrm{~kg} / \mathrm{m}^{2}$ of precipitable water. After the initiation of convection at 14:00 UTC, the maximum convective activity has been registered from 17:00 to 18:00 UTC with the maximum number of new cells, maximum reflectivity $(62 \mathrm{dBZ})$ and maximum hailstone diameter (34.6 mm).

The application of the meteorological radar has allowed identifying and tracking two main systems: one related with the largest hailstone $(34.6 \mathrm{~mm})$ in the hailpad-covered area (case 1) and the other one related to the longest life cell of the 
Table 5. Life time evolution of radar parameters of 11 September 2004 Alcarrás-Fraga cell (16:40 UTC - 18:30 UTC): Maximum reflectivity (Zmax), Mean reflectivity (Zmean), Vertical Integrated Liquid (VIL), VIL density (VILD), Kinetic energy (KE), Hail probability (HP), Severe hail probability (SHP) and Maximum expected hail size (MEHS).

\begin{tabular}{|c|c|c|c|c|c|c|c|c|c|c|}
\hline Time (UTC) & Hail & Longitude & Latitude & $\mathrm{Z}_{\max }(\mathrm{dBZ})$ & $\mathrm{Z}_{\text {mean }}(\mathrm{dBZ})$ & $\operatorname{VIL}\left(\mathrm{kg} / \mathrm{m}^{2}\right)$ & $\operatorname{VILD}\left(\mathrm{g} / \mathrm{m}^{3}\right)$ & $\mathrm{KE}\left(\mathrm{J} / \mathrm{m}^{2}\right)$ & MEHS (mm) & SHP (\%) \\
\hline 1820 & Yes & 0.788 & 41.639 & 49.2 & 43.7 & 14.7 & 1.7 & 202.2 & 26.66 & 48.7 \\
\hline 1800 & Yes & 0.639 & 41.672 & 54.0 & 42.5 & 18.4 & 2.2 & 323.0 & 37.86 & 57.5 \\
\hline 1750 & No data & 0.537 & 41.672 & 50.0 & 42.5 & 12.7 & 1.8 & 192.0 & 19.88 & 41.3 \\
\hline 1740 & Yes & 0.404 & 41.648 & 56.8 & 45.3 & 39.8 & 3.8 & 988.8 & 64.41 & 70.9 \\
\hline 1710 & No data & 0.273 & 41.505 & 52.0 & 42.1 & 8.5 & 1.9 & 140.0 & 41.82 & 60.0 \\
\hline 1700 & No data & 0.177 & 41.464 & 62.0 & 50.4 & 54.1 & 5.1 & 1724.8 & 81.46 & 76.8 \\
\hline 1650 & No data & 0.164 & 41.423 & 53.2 & 42.6 & 20.3 & 2.4 & 401.9 & 46.68 & 62.8 \\
\hline 1640 & No data & 0.130 & 41.388 & 35.6 & 33.0 & 0.7 & 0.3 & 0.0 & 0.00 & 0.0 \\
\hline
\end{tabular}

Table 6. Life time evolution of radar parameters of 11 September 2004 La Cerollera-Rafales-Fuentespalda-Beceite cell (15:30 UTC - 17:30 UTC): Maximum reflectivity (Zmax), Mean reflectivity (Zmean), Vertical Integrated Liquid (VIL), VIL density (VILD), Kinetic energy (KE), Hail probability (HP), Severe hail probability (SHP) and Maximum expected hail size (MEHS).

\begin{tabular}{ccccccccccc}
\hline Time $(\mathrm{UTC})$ & Hail & Longitude & Latitude & $\mathrm{Z}_{\max }(\mathrm{dBZ})$ & $\mathrm{Z}_{\text {mean }}(\mathrm{dBZ})$ & $\mathrm{VIL}\left(\mathrm{kg} / \mathrm{m}^{2}\right)$ & $\mathrm{VILD}\left(\mathrm{g} / \mathrm{m}^{3}\right)$ & $\mathrm{KE}\left(\mathrm{J} / \mathrm{m}^{2}\right)$ & MEHS $(\mathrm{mm})$ & $\mathrm{SHP}(\%)$ \\
\hline 1730 & No data & 0.766 & 40.910 & 44.0 & 36.0 & 0.0 & 0.0 & 6.0 & 7.43 \\
17200 & No data & 0.668 & 40.886 & 52.0 & 42.1 & 20.1 & 1.9 & 362.9 & 27.83 & 46.5 \\
1710 & No data & 0.567 & 40.884 & 52.0 & 44.0 & 17.0 & 2.8 & 390.7 & 41.01 & 59.5 \\
1700 & No data & 0.453 & 40.868 & 53.6 & 46.1 & 28.9 & 2.8 & 603.1 & 61.38 & 69.7 \\
1650 & No data & 0.374 & 40.867 & 55.2 & 49.4 & 39.5 & 3.8 & 962.5 & 68.84 & 72.6 \\
1640 & Yes & 0.239 & 40.835 & 55.2 & 47.8 & 41.5 & 3.3 & 859.2 & 80.20 & 76.4 \\
1630 & Yes & 0.181 & 40.831 & 55.6 & 48.2 & 45.2 & 3.6 & 1052.4 & 74.47 & 74.6 \\
1620 & Yes & 0.104 & 40.832 & 54.4 & 49.2 & 36.6 & 3.5 & 717.9 & 84.09 & 77.6 \\
1610 & Yes & 0.025 & 40.861 & 55.2 & 48.4 & 45.6 & 3.6 & 972.9 & 85.87 & 78.1 \\
1600 & Yes & -0.058 & 40.850 & 55.2 & 48.2 & 38.5 & 3.1 & 831.9 & 64.10 & 70.8 \\
1550 & No data & -0.124 & 40.821 & 48.0 & 42.0 & 5.6 & 1.6 & 84.8 & 30.41 & 52.0 \\
1540 & No data & -0.160 & 40.832 & 47.6 & 44.7 & 1.8 & 1.8 & 45.4 & 0.00 \\
1530 & No data & -0.269 & 40.808 & 48.8 & 38.2 & 7.7 & 1.3 & 85.3 & 9.3 & 0.0 \\
\hline
\end{tabular}

non-hailpad-covered area (case 2). The evolution has shown the systems started as isolated convection that lasted around 40 minutes. Then, they developed into a multicellular system and the largest hailstones were produced. As a multicellular system they lasted around 1 and $1.5 \mathrm{~h}$. In some occasions, if VIL oscillations are considered, it is possible to conclude that more than one cell was developed along the track. Hailproducing cells have been characterised by the high values of radar parameters: VIL, VILD, HP, SHP, KE, Zmax, Zmean, etc. Generally values of VIL, VILD, HP, SHP and Zmax are above $35 \mathrm{~kg} / \mathrm{m}^{2}, 7 \mathrm{~g} / \mathrm{m}^{3}, 100 \%, 70 \%$ and $54 \mathrm{dBZ}$, respectively

The comparison of TITAN and RHAP methods has shown similar results when the hail was associated to a main cell. On the contrary, if hail could be associated to different cells into a MUL system the RHAP methods would be more useful
Table 7. Pearson, Kendall's $\tau_{b}$ and Spearman's $\rho$ correlation coefficients between TITAN and RHAP track methods for the Cerollera, Rafales, Fuentespalda and Beceite cell.

\begin{tabular}{llll}
\hline & \multicolumn{3}{c}{ Correlation coefficients } \\
\hline Variable & Pearson & Kendall's $\tau$ b & Spearman's $\rho$ \\
\hline Top TITAN/Top RHAP & $0.684^{* *}$ & $0.478^{*}$ & $0.641^{*}$ \\
Volume TITAN/Volume RHAP & $0.744^{* *}$ & $0.513^{*}$ & $0.720^{* *}$ \\
Z(dBZ) TITAN/Z(dBZ) RHAP & $0.693^{* *}$ & $0.521^{*}$ & $0.719^{* *}$ \\
\hline
\end{tabular}

* The correlation is significant at the $95 \%$ confidence level.

** The correlation is significant at the $99 \%$ confidence level. 
because it could distinguish the internal system structure and its life cycle.

Further studies will be based on this kind of analysis to characterise hail phenomena and will improve the nowcasting of radar parameters of 3-D cells and precipitation systems.

Acknowledgements. The authors thank the MONEGRO (REN2003-09617-C02-02) Spanish project for enabling the drawing up and presentation of this contribution. Our thanks to the Associació de defensa dels Vegetals, Maite Torà and Marta Masot, to the Meteorological Service of Catalonia of the Generalitat de Catalunya and to the Instituto Nacional de Meteorología for the hailpad data, radiosonde data and radar data. And, finally, thanks to the University of León and the observers of Aragón for ground truth data.

Edited by: V. Kotroni and K. Lagouvardos

Reviewed by: T. Karacostas

\section{References}

Amburn, S. and Wolf, P.: VIL Density as a Hail indicator, Wea. Forecasting, 12, 473-478, 1997.

Browning, K. A.: The structure and mechanism of hailstorms, Meteorol. Monogr., 16, 38, 1-39, 1977.

Ceperuelo, M., Llasat, M. C., and Rigo, T.: Rainfall events and Hailstorms Analysis Program (RHAP), Adv. Geosci., in press, 2006.

Dixon, M. and Wiener, G.: Thunderstorm Identification, Tracking, Analysis and Nowcasting - A Radar-based Methodology, J. Atmos. Oceanic Technol., 10, 6, 785-797, 1993.

Font, I.: Climatological Atlas of Spain (in Spanish: Atlas Climático de España), INM and Ministerio de Transportes, Turismo y Comunicaciones, Madrid, 1983.

Fraile, R., Castro, A., Sánchez, J. L., Marcos, J. L., and López, L.: Noteworthy C-band radar parameters of storms on hail days in northwestern Spain, Atmos. Res., 59-60, 41-61, 2001.

Greene, D. R. and Clark, R. A.: Vertically Integrated Liquid: a new analysis tool, Mon. Wea. Rev., 100, 548-552, 1972.

Johnson, J. Y., MacKeen, P. L., Witt, A., Mitchell, E. D., Stumpf, G. J., Eilts, M. D., and Thomas K. W.: The Storm Cell Identification and Tracking (SCIT) Algorithm: An Enhanced WSR-88D Algorithm. Weather and Forecasting, June 1998, 13, 263-276, 1998.
Knight, C. A. and Knight, N. M.: Hailstorms. Severe Convective Storms, Meteorol. Monogr., 28, 50, 223-254, 2001

Llasat, M. C., Gibergans, J., Guilbaud, S., and Rodriguez, J. Y.: The use of the vertical thermodynamic data in the daily classification: application to the improvement of an analog technique, INM/WMO International Symposium on Cyclones and Hazardous Weather in the Mediterranean, Palma de Mallorca, 395-402, 1997.

López, L.: Atmospheric severe convection: forecasting and identificating hailstorms (in Spanish), Doctoral Thesis, University of León, 2003.

Martín, F., Eliazaga, F., Carretero, O., and San Ambrosio, I.: Deep convection diagnosis and prediction (in Spanish), STAP Technical note no. 35, 2001.

Pascual, R.: Study of hailstorms in the Lleida region (in Spanish), Technical note no. 3, Regional Meteorological Centre of Catalonia, 2000.

Paxton, C. H. and Shepherd, J. M.: Radar Diagnostic Parameters as Indicators of Severe Weather in Central Florida, NOAA Tech. Memo. NWS SR-149, 12, 1993.

Ragette, G.: Mesoscale Circulations Associated with Alberta Hailstorms, Mon. Wea. Rev., 101, 150-159, 1973.

Rigo, T.: Study of Occidental Mediterranean Convective Mesoscale Systems using meteorological radar (in Spanish), Doctoral Thesis, University of Barcelona, internal publication, 2004.

Rigo, T. and Llasat, M. C.: A methodology of convective structures using meteorological radar: application to heavy rainfall events on the Mediterranean coast of the Iberian Peninsula, Nat. Hazards Earth Syst. Sci., 4, 59-68, 2004.

San Ambrosio, I.: Radar-based module for hail estimation (in Spanish), STAP Technical Note no. 44, 2005.

Sánchez, J. L., Fernández, M. V., Fernández, J. T., Tudurí, E., and Ramis, C.: Analysis of mesoscale convective systems with hail precipitation, Atmos. Res., 67-68, 573-588, 2003.

Schleusener, R. A. and Jenings, P. C.: An energy method for relative estimates of hail intensity, Bull. Amer. Meteor. Soc., 41, 372376, 1960.

Waldvogel, A., Federer, B., Schmid W., and Mezeix, J. F.: The kinetic energy of hailfalls. Part II. Radar and hailpads, J. Appl. Meteorol., 17, 1680-1693, 1978.

Waldvogel, A., Federer, B., and Grimm, P.: Criteria for the detection of hail, J. Appl. Meteorol., 16, 1521-1525, 1979.

Witt, A., Eilts, M. D., Stumpf, G. J., Johnson, J. T., Mitchell, E. D., and Thomas, K. W.: An enhanced hail detection algorithm for the WSR-88D, Wea. Forecasting, 13, 286-303, 1998. 